\title{
Managerial Mindsets Toward Corporate Social Responsibility: The Case of Auto Industry in Iran
}

\author{
Ebrahim Soltani $\cdot$ Jawad Syed $\cdot$ Ying-Ying Liao • \\ Abdullah Iqbal
}

Received: 1 August 2012/Accepted: 1 June 2013/Published online: 17 April 2014

(C) Springer Science+Business Media Dordrecht 2014

\begin{abstract}
Despite a plethora of empirical evidence on the potential role of senior management in the success of corporate social responsibility (CSR) in Western-dominated organizational contexts, little attempt has been made to document the various managerial mindsets toward CSR in organizations in Muslim-dominated countries in the Middle East region. To address this existing lacuna of theoretical and empirical research in CSR management, this paper offers a qualitative case study of CSR in three manufacturing firms operating in Iran's auto industry. Based on an inductive analysis of the qualitative data, three types of managerial mindset toward CSR are identified: conformist, self-seeker, and satisfier. While it is evident that these different mindsets of Iranian managers seek to serve managerial ends and short-term self-interests, they fall short of core values of Islamic ethics and CSR.
\end{abstract}

Keywords Corporate social responsibility · Iran · Islamic business ethics - Managerial mindset

\section{E. Soltani $(\bowtie)$}

School of Business \& Quality Management, HBMSU,

P.O. Box 71400, Dubai Academic City, Dubai, UAE

e-mail: e.soltani@hbmeu.ac.ae

J. Syed

University of Huddersfield Business School, Huddersfield,

West Yorkshire, UK

e-mail: j.syed@kent.ac.uk

\section{Y.-Y. Liao}

Department of Business, Economics and Management, Xi'an Jiaotong-Liverpool University, Suzhou, Jiangsu, China

e-mail: yingying.liao@xjtlu.edu.cn

A. Iqbal

Kent Business School, University of Kent, Kent, UK

e-mail: A.Iqbal@kent.ac.uk

\section{Introduction}

There is a burgeoning theoretical and empirical literature on the adoption and implementation of corporate social responsibility (CSR) in "advanced industrialized nations" in the West, as well as in "emerging market economies" (CIA 2013; Carroll 1999; Chambers et al. 2003; Matten and Moon 2008; Fukukawa and Teramoto 2009; Jamali 2007; Cheung et al. 2010; Yin and Zhang 2012; Khan et al. 2013). Financial benefits such as profit maximization and non-financial benefits such as talent management (Bhattacharya et al. 2008), risk aversion (Kytle and Singh 2005), and brand differentiation (Paluszek 2005) have been frequently cited as incentives for managers to be socially responsible (see Waldman et al. 2004). Although these studies have made significant contributions toward conceptualization of CSR, there remains a need for a critical analysis of the national and industry contexts that influence managerial attitudes toward CSR.

With regards to the potential role of senior management in the CSR practice, Waldman et al. (2004, p. 4) note that the existing perspectives and models of CSR "do not take into account the personal attributes or qualities of senior managers which may also affect the extent to which firms engage in CSR" (see also Maak and Pless 2009). In particular, there is a dearth of research on organizational and managerial perspectives of CSR in non-Western organizational contexts (see Metcalfe and Syed 2012). This dearth is also found in the Muslim-dominated Middle East region where CSR is generally regarded as a common ethical message for personal, social, and business conduct (Dusuki 2008; Williams and Zinkin 2010; Syed 2009; Beekun and Badawi 2005; Metcalfe and Rees 2010). That is, businesses and individuals are expected to commit themselves to their contractual obligations and lead a 
virtuous life in accordance with the Islamic Shariah (referred to as the kernel of Islamic law and the epitome of Islamic thought) (Dusuki 2008; Dusuki and Bouheraoua 2011).

Given a shortage of studies of CSR management in the Middle East and the prime importance of Islamic values in everyday life, empirical evaluations are needed to explore "Islamic business ethics and leadership" (see Metcalfe and Syed 2012) and delineate managerial mindsets toward CSR (see Waldman et al. 2004, p. 4). The present study is designed to advance theoretical and empirical debate on CSR management by illustrating the various managerial mindsets of Iran's (the second largest country in the Middle East) auto industry-the country's biggest non-oil industry which is the largest in the Middle East and 12th largest worldwide (Samani et al. 2011).

For the purposes of this paper, the term managerial mindset refers to a manager's mental attitude that influences her or his responses to and interpretations of a firm's responsibility for its actions and the resulting implications for wider stakeholders (see Wood 1991; Freeman 1984; The Free Dictionary 2013a, b). The term managerial leadership connotes "a process of influencing others to understand and agree about what needs to be done and how to do it, and the process of facilitating individual and collective efforts to accomplish shared objectives" (Yukl 2012 , p. 8). As such, CSR is used as an umbrella term to refer to a corporation's built-in, self-regulating ethical standards, policies, and practices that reflect its responsibility for wider societal good (Freeman 1984; Moon et al. 2005; Crane et al. 2008). By the Middle East region, we refer to "the lands around the southern and eastern shores of the Mediterranean Sea, extending from Morocco to the Arabian Peninsula and Iran" (Encyclopedia Britannica 2013, para. 1).

The paper is structured as follows. First, we present a literature review of the role of management in CSR practices. We then explain our methodological approach in terms of the research site, data collection and analysis, and the propositions emerging from the within-case and crosscase analyses. The final section offers conclusions and also identifies some implications for future research.

\section{Managing CSR Practices: The Role of Management in the Realization of its Potential}

Previous research indicates that the potential of CSR to create organizational legitimacy and serve public interest depends, in the main, on the managerial discretion (Ackerman 1975; Sheth and Babiak 2010; Wood 1991). The significance of managerial discretion is particularly highlighted in the work of Ackerman (1975). According to Ackerman, managerial discretion is the essence of CSR.
The emphasis here is not so much philanthropy or community involvement but on "the discretion extant in the total realm of managerial actions and choices" (Wood 1991, p. 699; see Storey 1992, p. 29). However, the managerial discretion aspect of CSR-originally envisaged by Ackerman-has not been sufficiently investigated. A review of this vital issue constitutes the focus of the remainder of the literature review section.

The literature on CSR has centered on management orientation and mindset as the main driving force in directing an organization toward socially responsible goals (Swanson 2008). Since 1950s, scholars have offered a variety of models and perspectives to explain the rationale behind a manager's discretion to be attentive to the society's unspoken expectations of the firm or a firm's explicit responsibility toward society (see Chase et al. 1950; Bowen 1953). The literature suggests that a dominant managerial approach to CSR has been to pursue CSR instrumentally. The mixed instrumental-strategic approach to CSR chronicled by Friedman (1970), Freeman (1984), Wright and Ferris (1997), Russo and Fouts (1997), and McWilliams and Siegel (2001) makes explicit a set of assumptions which act as guiding parameters for managerial orientation toward CSR. Derived from several organisational theories such as agency theory (Rees 1985; Eisenhardt 1989), resource-based view (Penrose 1959), and theory of the firm (Kantarelis 2007), the instrumental use of CSR by managers is attributed to several factors, inter alia, the fulfillment of individual interests, profit maximization, meeting the needs, and requirements of various stakeholder groups - to name but a few (see Waldman et al. 2004).

Another strand in the literature on CSR management is the justification and analysis of the potential impact of managerial values and attitudes toward CSR (see Hay and Gray 1974; Hemingway 2005; Williams and Aguilera 2007, pp. 460-464). Some common themes emerge in this literature. A consistent theme is the existence of a linear correlation between the adopted managerial values and attitudes and firm-level CSR outcomes. For example, Williams and Aguilera's (2007) thorough review of cross-cultural studies of managerial values and attitudes toward CSR shows that managers act differently and adopt various values and attitudes toward CSR for a number of reasons, namely, the national cultural norms of work (Hofstede 2001; Schwartz 1994; Triandis 1995), organisational culture (O'Reilly and Chatman 1996; Schein 1992; Vitell and Paolillo 2004), and profession (Sirmon and Lane 2004). One important conclusion of Williams and Aguilera's review (2007, pp. 461-463) is that managerial values and attitudes toward CSR vary across countries and that forces such as hyper (fundamental principles) and local norms, social institutional constraints, and the level of industrialisation could trigger differences in managerial attitudes toward CSR (e.g., Donaldson and 
Dunfee 1999; Spicer et al. 2004; Cullen et al. 2004; Waldman et al. 2006; Egri et al. 2006; for a review see Williams and Aguilera 2007, pp. 460-465).

While the aforementioned studies led the way with their hypothesized connection between managerial attitudes and performance impact of CSR activities at organisational and country-level of analysis, other scholars (Quazi 1997; Quazi and O'Brien 2000; Bansal and Roth 2000) have found the so-called causal linkage between CSR managerial attitudes and firm-level CSR outcomes to be fraught with immense difficulty not least because of the vast range of confounding forces and variables (Storey 1992, p. 40). Proponents of this view lay stress on the mindsets of individual managers and organisational values (regardless of the country or regional, institutional and cultural context) as strong predictors of managerial CSR decision making (Williams and Aguilera 2007).

While these studies-albeit with mixed and contrasting findings - have made substantial contributions to the fields of CSR and business ethics, they can be criticized on two accounts. First, existing conceptualisations of CSR management do not seem to document the various managerial mindsets which could bring about different firm-level CSR outcomes. While our concern in this paper is not to assess the efficacy of CSR activities and evaluate their firm-level outcomes, we argue that the the existing CSR literature could be enriched by an elucidation of managerial CSR attitudes. Second, the methodological focus of current CSR research is not only dominated by quantitative methods but also the focus of such empirical inquiry represents the dominant Western values - thereby devoid of critical analysis of CSR management in non-Western organisational contexts. There is, in particular, a shortage of studies of CSR with a focus on Muslim-dominated countries, including but not limited to the Middle East region. Despite some recent attempts to explore CSR in developing countries and emerging economies (e.g., Khan et al. 2013; Fukukawa and Teramoto 2009; Jamali and Sidani 2012; Visser 2011), the Middle Eastern countries have received limited attention from CSR scholars. Indeed, the existing CSR research in the Middle East weighs heavily toward the adoption of the Western-led CSR interventions (see Jamali and Mirshak 2007; Jamali and Neville 2011), with insufficient theoretical and empirical scrutiny of local managerial mindsets toward CSR. This paper makes an attempt to address this imbalance by exploring the various managerial mindsets toward CSR based on a qualitative study of the auto industry in Iran.

\section{Methodology}

To achieve our research aim of identifying the various managerial mindsets toward CSR, a qualitative case study approach was adopted. The approach was chosen in view of the lack of plausible theory and empirical evidence regarding the nature of managerial mindsets toward CSR. The approach is also appropriate in view of the multidisciplinary nature of the field of managerial leadership. That is, the study of managerial leadership is a "contextdependent" phenomenon, which necessitates the use of qualitative case study to produce thick and rich descriptions of the "context" or provide, as Guba and Lincoln (1994, p. 106) suggest, "contextual information" (see also Eisenhardt 1989; Waldman et al. 1998; Yin 2003).

\section{Research Site}

The empirical study was conducted in auto industry in the Islamic Republic of Iran. As the most populous country of the Middle East (with a population of over 78 million), and one of the largest economies in the region, Iran has a long history of political sovereignty than virtually any other modern Muslim state (Wright 2010, 2012). Since its Islamic revolution (perceived as one of the three major transformative events in the Middle East in the twentieth century), Islam has been a dominant religious force and indeed, a center of governance with profound effect on Iran's societal and cultural fabric (Eshghipour 2013). The Islamic dominance in Iran has paved the way for Muslim clerics to serve as the "architects" to translate and inject the fundamental notions and the core values of Islam into modern twentieth century Iran (see Amuzegar 1991).

While Shia Muslims constitute $38 \%$ of Muslims in the Middle East and 10-15\% of the worldwide Muslim community, they constitute a dominant majority in Iran (Mehler 2008). Approximately $89 \%$ of Iranians are Shia and some $9 \%$ are Sunni. The Shia and the Sunni branches of Islam share the five fundamental Islamic beliefs which are obligatory and form the foundation of Muslim life. These beliefs which are also called the five pillars of Islam are as follows: Shahada (the declaration of faith and trust), Salat (prayer), Zakat (alms-giving), Sawm (fasting), and Hajj (pilgrimage to Mecca). However, the rift between the two branches of Islam lies in their interpretation of the rightful succession of leadership after the death of the Prophet Muhammad. While in Sunni Islam a believer's relationship with God is assumed to be direct and clerics only act as guides and advisors on religious affairs, in Shia Islam, the descendants of the Prophet and on their behalf religious clerics are perceived as empowered to interpret God's word for the faithful (Wright 2012; Time Magazine 2007; Farah 1994; Momen 1985; Javidan and Dastmalchian 2003). Such fundamental differences between the two branches of Islam regarding the role of leadership not only highlight the fact that Shia clerics are possessed with an influential authority in telling a believer what is right or 
wrong, but also raise the question of how far the Iranian managers genuinely believe in the moral and ethical bases of leadership from an Islamic perspective.

The commonly found managerial and cultural attributes in Iran, without any claim to generalization, may be explained through Hofstede (2001) 5-D cultural model. High power distance of Iranian managers is attributed to their autocratic leadership style and their top-down directive approach. The highly individualist culture lays stress on individual as the most important unit with regard to their self-orientation, "I" mentality, individual achievement and a dominant guilt culture. High preference for uncertainty avoidance not only advocates rigid codes of belief and behavior but more importantly is intolerant of unorthodox behavior and ideas. Despite such desire for uncertainty avoidance, research evidence indicates a lack of rule orientation of Iranian businesses, largely due to unclear and often changing rules. The GLOBE study of cross-cultural values has indicated the prevalence of patriarchy in Iran and more importantly the lack of future-oriented behaviors by Iranian managers (see House et al. 2004; Javidan and Carl 2004; Javidan and Dastmalchian 1998, 2003).

Owing to world's third largest petroleum reserves (after Saudi Arabia and Canada), second largest gas reserves (after Russia), and second largest population in the region (after Egypt), Iran has the second largest economy in the Middle East and North Africa (MENA) region (Ilias 2009). The country's economy is largely state owned and dominated by oil and gas production. Despite young and educated population and abundant natural resources, Iran's economy faces a number of crippling challenges at two fronts: internal and external. Examples of the micro-and macro-level internal challenges include: high unemployment and poverty levels, economic mismanagement and inefficiency, government's dependence on oil revenues, and vulnerability to oil price fluctuation. At the core of the external challenge is the U.S. led sanction on Iran since Iran's 1979 Islamic revolution. The US-led sanctions have not only brought difficulties to Iran's oil-dominated economy but also caused catastrophic humanitarian consequences for ordinary citizens (Ilias 2009; Amuzegar 1997; Katzman 2013). This political context has led to Islam versus West polarization in at least some sections of the Iranian society.

To empirically investigate Iranian managers' mindsets toward CSR, the automotive industry was chosen as the primary focus of the present study. The reasons for choosing the automotive industry lies in several important factors, inter alia, contribution to over $10 \%$ of Iran's GDP, the second most active and fast-growing industry (after oil and gas industry), the Middle East largest automobile producer and consumer, and the 12th biggest automaker in the world (see Recknagel 2013; Dubowitz 2013). The
Table 1 An overview of the sample cases

\begin{tabular}{|c|c|c|c|}
\hline & Automotive1 & Automotive2 & Automotive3 \\
\hline $\begin{array}{l}\text { Year } \\
\text { established }\end{array}$ & $1960 \mathrm{~s}$ & $1960 \mathrm{~s}$ & $1960 \mathrm{~s}$ \\
\hline $\begin{array}{l}\text { Scope of } \\
\text { operations }\end{array}$ & $\begin{array}{l}\text { Domestic and } \\
\text { global }^{\mathrm{a}} / \\
\text { worldwide }\end{array}$ & $\begin{array}{l}\text { Domestic and } \\
\text { regional }^{\mathrm{b}}\end{array}$ & $\begin{array}{l}\text { Domestic and } \\
\text { global }\end{array}$ \\
\hline $\begin{array}{l}\text { Main product } \\
\text { portfolio }\end{array}$ & $\begin{array}{l}\text { Passenger car, } \\
\text { truck, bus, } \\
\text { minibus }\end{array}$ & $\begin{array}{l}\text { Truck, trailer, } \\
\text { truck bodies } \\
\text { and parts }\end{array}$ & $\begin{array}{l}\text { Tractor/ } \\
\text { agricultural } \\
\text { machinery }\end{array}$ \\
\hline Ownership & Private sector & Private sector & Public sector \\
\hline $\begin{array}{l}\text { Organizational } \\
\text { size (no. of } \\
\text { employees) }\end{array}$ & $>2,300$ & $>1,900$ & $>1,350$ \\
\hline $\begin{array}{l}\text { Scope of } \\
\text { partnership }\end{array}$ & $\begin{array}{r}\text { Asia and } \\
\text { Europe }\end{array}$ & $\begin{array}{r}\text { Asia and } \\
\text { Europe }\end{array}$ & $\begin{array}{l}\text { Canada/USA, } \\
\text { Eastern } \\
\text { Europe }\end{array}$ \\
\hline $\begin{array}{l}\text { Foreign } \\
\text { partner(s) }\end{array}$ & $\begin{array}{l}\text { Peugeot } \\
\text { (France), } \\
\text { Suzuki } \\
\text { (Japan), } \\
\text { Renault } \\
\text { (France), } \\
\text { Sedan } \\
\text { (China) }\end{array}$ & $\begin{array}{l}\text { Foton (China), } \\
\text { Volvo } \\
\text { (Germany), } \\
\text { Renault } \\
\text { (France) }\end{array}$ & $\begin{array}{l}\text { Canada } \\
\text { (Massy } \\
\text { Ferguson), } \\
\text { Romania, } \\
\text { AGCO } \\
\text { (Middle East } \\
\text { Center) }\end{array}$ \\
\hline Foreign-site & $\begin{array}{l}\text { Yes (e.g., Latin } \\
\text { America) }\end{array}$ & $\begin{array}{l}\text { Yes (e.g., } \\
\text { Africa) }\end{array}$ & $\begin{array}{l}\text { Yes (e.g., } \\
\text { Latin } \\
\text { America, } \\
\text { Africa, } \\
\text { middle East) }\end{array}$ \\
\hline $\begin{array}{l}\text { The nature and } \\
\text { frequency of } \\
\text { CSR } \\
\text { activities }\end{array}$ & $\begin{array}{l}\text { A dominant } \\
\text { tradition of } \\
\text { philanthropy } \\
\text { on a regular } \\
\text { annual basis; } \\
\text { Partnership } \\
\text { with } \\
\text { government } \\
\text { agencies }\end{array}$ & $\begin{array}{l}\text { Corporate } \\
\text { philanthropy; } \\
\text { Employee } \\
\text { volunteering; } \\
\text { Working with } \\
\text { NGOs }\end{array}$ & $\begin{array}{l}\text { Philanthropic } \\
\text { measures on } \\
\text { an needed } \\
\text { basis; } \\
\text { Voluntary } \\
\text { community } \\
\text { services on } \\
\text { an ad hoc } \\
\text { basis }\end{array}$ \\
\hline
\end{tabular}

${ }^{a}$ Regional market refers to the Middle East, Central Eurasia (Southern and Western Asia) and North Africa territories

b Global market extends beyond the regional market and is also inclusive of international auto market

industry's sheer size and importance puts the onus on its senior management and policy makers to look beyond "the fulfillment of core profit-making responsibility" (Matten and Moon 2008, p. 405).

Given the familiarity and experience of the lead author with the research context, we asked several senior managers and auto industry consultants to assist us with selecting several cases based on three criteria. First, the case had to operate in a global industry-as opposed to merely competing in the national market (see Makhija et al. 1997; Porter 1986). Second, it had to be actively involved in and continuously strive to lead in the adoption of CSR interventions. Finally, it had to have a dedicated functional 
unit which monitors delivering objective and tangible solutions to the existing and new environmental and social challenges.

In light of these selection measures, we gained access to nine firms - of which only three (referred to in this research paper under the pseudonym of Automaker 1, Automaker 2, and Automaker 3) fully met the selection criteria. The selection of these three auto firms as our research sites "reduced extraneous variation and clarified the domain of the findings" (Eisenhardt 1989, p. 537) for several reasons, namely, similarity in their organizational size, product, and service portfolio, catering sales of different types of vehicles, rendering after-sale services, distributing auto parts requirements, and more importantly joint collaboration with several leading European and Asian automakers (e.g., Peugeot, Renault, Foton, Kia, Daewoo, Nissan, Toyota, Proton). Table 1 presents an overview of each of the three cases.

\section{Data Collection}

Due to the inductive nature of our qualitative study, multiple data collection methods were used. Data were collected predominantly through semi-structured interviews, as well as factory tours and archival sources. The data collection continued until we reached theoretical saturation, i.e., until we uncovered no new data (Glaser and Strauss 1967; Guba 1978; Maykut and Morehouse 1994). As a result, a total number of 51 interviews were carried out. Also, one focus group was conducted per case organization. Given the high degree of functional hierarchy in Iranian organizations, and consistent with the system-level perspective of CSR, interview data were collected from various functional hierarchies of policy and decision makers in each case (see Waldman et al. 1998; Harris and Ogbonna 2002).

The single focus group per case was carried out at the preliminary stage of the research to fulfill several purposes, inter alia, to elicit diverse views and reactions toward adoption, adaptation, and execution of CSR interventions, to facilitate the design and development of the follow-up individual interviews, and to serve as a means of "crosschecking individual face-to-face interview data for further exploration of any (ir)regularities in the research data" (see O’Donoghue and Punch 2003).

The individual semi-structured interview questions focused on personal and career backgrounds of the interviewees and their orientations toward CSR interventions. The individual semi-structured interviews lasted, on average, around $90 \mathrm{~min}$ and were conducted by a team of two researchers. In case of the focus groups, they varied from two to two and a half hours and were conducted by a team of three researchers where the lead investigator served as the moderator of the focus group. Interviews and focus groups were conducted in both Farsi (the Iranian language) and English and the former were then translated back to English. They were tape-recorded and transcribed verbatim (except in a few cases where the interviewees preferred not to use a tape recorder and consequently notes were taken on both the content and context of the interview). Table 2 presents an overview of key informants in each of the three cases.

\section{Data Analysis}

In order to inductively generate theory from the case studies, the analysis methods employed in this research included both within-case and cross-case data analysis (Eisenhardt and Graebner 2007). As a part of the withincase analysis, a detailed case study write-up for each of the three cases was prepared to further assist the research team "to become intimately familiar with each case as a standalone entity" (Eisenhardt 1989, p. 540). This process established a platform to elucidate the unique emerging patterns of each case for the follow-up generalization across all cases (i.e., cross-case analysis). In the cross-case analysis, the focus was on searching for cross-case patterns and identifying "within-group similarities coupled with intergroup differences" (Eisenhardt 1989, p. 540).

To conduct the comparative analysis in a more systematic way, the transcripts of all the data (e.g., interviews notes, field observations/factory tours, and secondary data such as documentary evidence and records) in each case were juxtaposed with the data from other cases. To become more familiar with the data, the transcripts were thoroughly read and reviewed multiple times by each member of the research team and notations were made to record any issue pertinent to the scope of and approach to CSR management. The initial or preliminary exploratory analysis or as Creswell (2005) put it, "bottom-up approach" was then extended by the research team in the sense that the identified initial themes were further revisited through the lens of the key research aim-i.e., to explore the various managerial mindsets toward CSR. Finally, the resulting themes and sub-themes of each case were corroborated and any conflicts and differences were debated in a joint meeting of the research team. This process resulted in, as Landis and Koch (1977) put it, a perfect (complete) interrate agreement-i.e., $97 \%$ (see Cohen 1960; Denzin and Lincoln 1994).

In a manner consistent with Eisenhardt's (1989) suggestion for shaping hypotheses, and previous qualitative theory building from case studies, we discussed our final results and working propositions with a sample of key research informants. Referred to as "reality test" (Eisenhardt 1989) in 
Table 2 Profile of the interviewees
${ }^{a}$ Hierarchy:

$\mathrm{SM}[\mathrm{MM}] \mathrm{FLM}=$ Senior

Manager [Middle Manager]

First Line Manager

${ }^{b}$ Function:

$\mathrm{HR}[\mathrm{POM}] \mathrm{M}[\mathrm{F}]=$ Human

Resources [Production and

Operations Management]

Marketing [Finance]

c Education:

$\mathrm{D}[\mathrm{C}] \mathrm{UG}[\mathrm{PG}]=$ Diploma

[College] Undergraduate

[Postgraduate]

\begin{tabular}{|c|c|c|c|}
\hline $\begin{array}{l}\text { Characteristics of interview } \\
\text { participants }\end{array}$ & Automotive 1 & Automotive2 & Automotive3 \\
\hline \multicolumn{4}{|l|}{ Managerial interviewees } \\
\hline a. Hierarchy: SM[MM]FLM ${ }^{\mathrm{a}}$ & SM[MM]FLM & SM[MM]FLM & SM[MM]FLM \\
\hline $\begin{array}{l}\text { b. Number of interviews per } \\
\text { hierarchy (excluding non- } \\
\text { managerial participants) }\end{array}$ & $4[6] 6$ & $3[6] 5$ & $4[7] 4$ \\
\hline c. Function: HR[POM]M[F $]^{\mathrm{b}}$ & HR, POM, M & $\mathrm{HR}, \mathrm{POM}, \mathrm{M}, \mathrm{F}$ & HR, POM, M, \\
\hline \multicolumn{4}{|c|}{ Non-managerial(professional/expert) interviewees } \\
\hline a. Field of expertise & $\begin{array}{l}\text { Business law, } \\
\text { customer } \\
\text { service }\end{array}$ & $\begin{array}{l}\text { Continuous improvement } \\
\text { initiatives, environmental } \\
\text { compliance advisor }\end{array}$ & $\begin{array}{l}\text { Employee relations, } \\
\text { quality } \\
\text { management }\end{array}$ \\
\hline $\begin{array}{l}\text { b. Relationship with the } \\
\text { organization }\end{array}$ & $\begin{array}{l}\text { Adviser to } \\
\text { managing } \\
\text { director }\end{array}$ & $\begin{array}{l}\text { External consultant (led by } \\
\text { the managing director) }\end{array}$ & $\begin{array}{l}\text { Compliance advisor } \\
\text { (report to the } \\
\text { managing director) }\end{array}$ \\
\hline c. Number of interviews & 2 & 2 & 2 \\
\hline Education: $\mathrm{D}[\mathrm{C}] \mathrm{BSc}[\mathrm{PG}]^{\mathrm{c}}$ & $0[0] 4[14]$ & $0[0] 5[11]$ & $0[0] 3[14]$ \\
\hline $\begin{array}{l}\text { Tenure with the organization } \\
\text { (average-in years) }\end{array}$ & 11.5 & 9 & 10.5 \\
\hline $\begin{array}{l}\text { Managerial experience } \\
\text { (average-in years) }\end{array}$ & 14 & 16.5 & 17 \\
\hline $\begin{array}{l}\text { The primary source of } \\
\text { familiarity with CSR practices }\end{array}$ & $\begin{array}{l}\text { Embedded in } \\
\text { the university } \\
\text { curriculum }\end{array}$ & $\begin{array}{l}\text { Imposed governmental } \\
\text { regulatory standards }\end{array}$ & $\begin{array}{l}\text { Joint-partnership } \\
\text { with foreign-auto- } \\
\text { makers }\end{array}$ \\
\hline Total number of interviews & 18 & 16 & 17 \\
\hline
\end{tabular}

Within-Case Analysis

qualitative research, the necessary amendments were then made to the identified themes and proposed hypotheses (see Eisenhardt 1989, p. 542).

Following the aforementioned procedures (by Glaser and Strauss 1967; Eisenhardt 1989; Miles and Huberman 1994; Eisenhardt and Graebner 2007; Yin 2009), we elucidated three types of managerial mindsets toward CSR: conformist, self-seeker, and satisfier. These managerial mindsets reflect the relative ethical values of the Iranian managers in each case which in turn lay a foundation for their firm's CSR-related behaviors and actions. Further details on the study's findings are given in the following section.

\section{Findings}

In order to better understand the managerial mindsets toward CSR within the context of the three automotive cases, this section first describes the features of each single case. The description includes background information, the scope of CSR activities, and the actual practice of CSR management. Such "descriptive, narrative approach" of within-case analysis enabled the research team to allow the details of each case "to speak for itself," which in turn resulted in "minimal subjective interpretation" of withincase descriptions (see Barker et al. 2002, p. 222; Wu and Choi 2005, p. 32).

\section{Automotive1}

Headquartered in the capital (Tehran), Automotive1 was founded in 1960s and established its position as an affiliate of one of the leading and most successful car, truck, and auto parts manufacturers in the region. As a large-sized business with multiple brands, Automotive1 owned a network of local, regional, and international production and assembly plants and over hundreds of sales subsidiaries worldwide. A major driving force behind the competitiveness of Automotive1 was attributed to its joint partnership with several leading European and Asian car manufacturers (see http://www.shingoprize.org/). The nature of its partnership focused on operational excellence which put the stress on the idea of effective management of organizational resources through the application of continuous improvement tools and techniques.

According to the firm's quality control manager, the joint partnership entailed "a planned organization-wide improvement in product and service quality." The planning for operational improvement focused on the mixed composition of people-based, work-related, and customer-orientation aspects of quality. In the focus group meeting, it was claimed that the operational improvement plan pursued a threefold purpose: enhancing employees' welfare, profit maximization, and maximizing customer satisfaction. A 
majority of the interviewees interpreted such triadic approach to the organization, employees, and customers which in turn secured the economic interest of the firm as the firm's CSR approach. In order to glean ideas and better execute the plan, a team of managers visited several European-based auto makers affiliated to their partners. With the help of foreign partners, a policy document was produced to highlight the need for cross-functional cooperation, close working relationship with both upstream and downstream supply chain parties, and more specifically giving due regard to the interests of the wider community of stakeholders.

For a majority of the interviewees at the middle and supervisory level positions, the detailed dossier on operational excellence was limited in scope as it primarily favored the interests of the firms and its affiliates-with less explicit reference to the fulfillment of the societal and environmental challenges facing the industry. This point is best illustrated by the remarks of an assembly line manager as follows: "We operate in a very competitive industry which has very price sensitive customers. To me, the existence of cost-conscious customers in auto industry has led the way to invest more in affordable products which practically means compromising quality."

For a public relations manager, the actual practice of operational excellence and the firm's commitment to its environmental and societal performance were in sharp contrast to the very idea of CSR and business ethics. As he observed, "the role of quality improvement, employee satisfaction, customer satisfaction, and environmental concerns in realizing business and non-business values of CSR is very minimal." However, there was a prevailing view that (to quote a senior advisor to the firm) "compliance with governmental safety standards and direct environmental concerns for motor vehicles constitute the core element of the firm's social and environmental responsibility."

Such lip service to CSR was indicated most emphatically by a technical marketing manager who advocated the view that: "The idea of realizing CSR potentials in joint collaboration with foreign auto makers to maintain an acceptable level of product quality is a purely a marketing trick." This point is also echoed by a senior CSR consultant's comment that "In fact the reason for many fatal road accidents is attributed to the poor safety rating of foreignmade cars in the country" (see Mather et al. 2007).

\section{Automotive2}

Founded in 1960s, Automotive 2 was an affiliate of the largest manufacturers of truck, trailer, and truck bodies and parts. To further promote its brand in the domestic market and expand their reach beyond national borders, the company revisited its business strategy to encompass the wider impact of their business operations on the local and international communities. Referred to as "the firm's CSR action plan" by a public relations manager, the social, environmental, and sustainability concerns of their business operations was pursued through the twin facets of (i) an organization-wide commitment to continuous improvement and (ii) focus on performance excellence in terms of employee productivity and customer satisfaction.

To ensure successful execution of the firm's CSR action plan and also to secure its position in the competitive domestic and international markets, Automotive 2 made a deal for joint venture with several European top-selling car manufacturers. In the light of such strategic partnership, the firm had access to complementary capabilities and resources of its partners. As our interviews indicated, the basic operational premise of forming foreign partnership was to obtain new technological know-how as a means of both increasing the production capacity and enhancing product quality. It also served, as a dealer relationship manager put it, "to build, win and sustain customers' confidence in our products and after-sale services."

To make most of their partnership and counteract the perceived poor quality of home-made cars, the management of Automotive2 drafted a detailed medium-to-longterm plan titled "compliance policy" to serve a twofold purpose: to guide the employees to fully comply with the operational and manufacturing guidelines of the foreign partners, and to assist the organization to fulfill its mandate to ensure conformance to the statutory requirements governing the car industry. For several senior advisors, consultants, and managers with multi-functional experiences, the essence of the idea of "compliance policy" was widely viewed as a yardstick "to maintain effective working relationship at both intra- and inter-firm levels," "to establish an acceptable level of product and service quality," "to pursue the firm's economic interest," "to enhance customer satisfaction," and "to generate positive publicity and attention for our company."

However, the actual implementation plan which was guided from the top was characterized by a majority of the middle and first line managers as (to quote a first line manager) "self-absorbed-mentality." According to the first line manager interviewed, "They [top management] just want to be the center of attention and publicize their commitment and enthusiasm to modern management practices. But behind the scene, they look for those opportunities that only serve their self-interests. I mean they simply instruct us to do different things which have nothing in common with those widely publicized proposals and plans".

What is important about the aforementioned research evidence is that managers hardly refer to Islamic business 
ethics and Islamic CSR in their conduct as a part of Islamic or/and Iranian culture. The following excerpt shows how the current approach to the management of CSR serves as the exact antithesis of the teachings of Qur'an and Sunnah: "I do not really think our religious values inform the way that we formulate and operationalize our working practices. We do something which is far from the ethos of CSR but we call it CSR. It is more to do with the top management's own priorities and preferences and in fact the top management's own self-interest with no respect for the rest of the organization, stakeholders and the wider community." [Executive Advisor]

\section{Automotive3}

As an affiliate of a large auto maker in the country, Automotive 3 was founded in 1960s to manufacture a range of different commercial heavy and semi-heavy vehicles. Being a regional leader in manufacturing highly advanced varieties of commercial vehicles, the company marked its strong market position through the ownership of an extensive network of upstream and downstream auto part manufacturers. It possessed a diverse product portfolio and operated in several functional areas such as product design, research and development, and after-sale services.

In a manner similar to that of Auotmotive1 and Automotive2, the company had extensively invested in partnering with several leading Asian and European automakers. The underlying reason for the firm's concerted efforts in cooperative efforts with foreign firms was to enhance the brand's image, value, or as a brand marketing manager put it, "To counteract the stereotype that the production division of Iranian auto makers lacks appropriate quality control measures."

In a similar vein, a senior product and business planning manager noted that: "To better compete on our operational differentiation strategy, we have formed partnership with leading foreign auto makers to benefit foreign their exceptional technical expertise and innovative processes." For the interviewees, the resulting outcomes of the cooperative relationships were not only limited to "building a more strong brand and aggressive marketing strategies" but also encompassed partially the importance of (to quote a manager from public relations office) "responding to the ever-changing regulatory, societal, and environmental challenges."

However, the formation of partnership did not seem to change the prevalence of quality related issue in Iran's auto industry. For several business advisors, consultants, and middle-level managers, the claims made by the senior management to fulfill the diverse and seemingly opposing interests of employees, organization, customers, and other stakeholders rarely went beyond the compliance threshold imposed by the external and independent regulatory agencies. One manager from quality assurance and control department provided a compelling and lucid account of the situation as follows: "Our [quality] management initiatives and the way we communicate them to the community of stakeholders are very detailed and thorough and indeed very eye-catching for our customers. But in reality they fall short of what we promise."

A contributing factor in sustaining this situation was cited to be the argument that (in the words of a manager from environmental health and safety unit): "We are not forced to fully comply with the safety, efficiency standards and consider our impact on the society and environment. We are facing a sharp increase in customer demand for making more cars. So we have shifted our focus from being a socially responsible car manufacturer to making more car, mass production, making more money, with no regard for the wider impact of our operations on the society."

Our analysis of the interviews indicates two important issues: the government is responsible for the protection and promotion of the industry, while the tendency of the top management is to maintain their own insular self-interest which is at odds with the fulfillment of the societal and environmental imperatives. From a religious point of view, a majority of the interviewees questioned the appropriateness of the existing organizational approach to CSR with those principles underpinning Shariah, such as taqwa (God-consciousness). One explanation for such lack of congruence between the two arises from the fact that the dominant managerial approach toward CSR does not assume "their role and responsibility as servants and vicegerents in all situations" (see Al-Attas 1996; Dusuki 2008).

\section{Cross-Case Analysis}

In an attempt to provide "vicarious experience" (Lincoln and Guba 1985, p. 359; see Ogbonna and Wilkinson 2003) of the management of CSR practices and create new knowledge through insights gained from individual case studies, we conducted cross-case comparisons. The outcomes of the cross-case comparisons helped elucidate the similarities and differences between various managerial mindsets toward CSR. Table 3 lists the identified themes across the three cases and highlights the unique features in each case. In the light of these identified mindsets, we now discuss both their points of commonality and differences.

\section{Points of Commonality}

As Table 3 indicates, there was sufficient evidence to establish some grounds for similarities across the case organizations. A brief account of these similarities is given below. 
Table 3 Cross-case analysis

\begin{tabular}{|c|c|c|c|}
\hline \multirow{2}{*}{$\begin{array}{l}\text { Identified } \\
\text { themes }\end{array}$} & \multicolumn{3}{|l|}{ Cases } \\
\hline & Automotive1 & Automotive2 & Automotive3 \\
\hline $\begin{array}{l}\text { Management } \\
\text { orientation } \\
\text { and } \\
\text { characteristics }\end{array}$ & $\begin{array}{l}\text { Conformist mindset } \\
\text { (conventional habits) } \\
\text { (orthodox) }\end{array}$ & $\begin{array}{l}\text { Ego-centric mindset (self- } \\
\text { seeker) }\end{array}$ & $\begin{array}{l}\text { Profit-centric mindset } \\
\text { (satisfier) }\end{array}$ \\
\hline $\begin{array}{l}\text { Primary driver } \\
\text { for CSR }\end{array}$ & $\begin{array}{l}\text { Personal desire to conform } \\
\text { to industry accepted } \\
\text { pattern of behavior; } \\
\text { compliance requirements } \\
\text { of the foreign-owned } \\
\text { joint venture partners }\end{array}$ & $\begin{array}{l}\text { Perceived self-relevant } \\
\text { and-self-centered } \\
\text { benefits of CSR; } \\
\text { compliance requirements } \\
\text { of the international joint } \\
\text { venture partners }\end{array}$ & $\begin{array}{l}\text { Potential for profit- } \\
\text { generating activities; } \\
\text { fulfillment of the } \\
\text { contractual joint venture } \\
\text { agreements with foreign } \\
\text { partners }\end{array}$ \\
\hline $\begin{array}{l}\text { Scope of CSR } \\
\text { practices }\end{array}$ & $\begin{array}{l}\text { Partial inter-organization } \\
\text { harmony-with a focus } \\
\text { on employees' basic } \\
\text { needs }\end{array}$ & $\begin{array}{l}\text { Functionally oriented CSR } \\
\text { activities-with a primary } \\
\text { focus on both centralizing } \\
\text { control as well as } \\
\text { functions with potential } \\
\text { for exercising more } \\
\text { internal control }\end{array}$ & $\begin{array}{l}\text { Functions with potential for } \\
\text { increasing efficiency and } \\
\text { opportunities for } \\
\text { generating large cost } \\
\text { savings }\end{array}$ \\
\hline $\begin{array}{l}\text { Strategic intent } \\
\text { for adopting } \\
\text { CSR practices }\end{array}$ & $\begin{array}{l}\text { Conformity to the } \\
\text { industry-wide } \\
\text { management practices } \\
\text { (ceremonious intent) }\end{array}$ & $\begin{array}{l}\text { Building and reinforcing a } \\
\text { high power distance } \\
\text { culture (a means of } \\
\text { inequalities in power) }\end{array}$ & $\begin{array}{l}\text { Short-run financial returns } \\
\text { and profit maximization }\end{array}$ \\
\hline $\begin{array}{l}\text { Perceived } \\
\text { positive } \\
\text { impact of } \\
\text { CSR practice }\end{array}$ & $\begin{array}{l}\text { Unclear and unconvincing, } \\
\text { incomprehensible, very } \\
\text { low CSR awareness }\end{array}$ & $\begin{array}{l}\text { Doubtful and unknown, } \\
\text { high level of skepticism, } \\
\text { very low CSR awareness }\end{array}$ & $\begin{array}{l}\text { Indistinct account of CSR } \\
\text { impact, a matter of } \\
\text { political rhetoric than } \\
\text { reality, very low CSR } \\
\text { awareness }\end{array}$ \\
\hline
\end{tabular}

Awareness and Understanding of CSR At the individual level, there was sufficient evidence to confirm that the interviewees were familiar with the board concept of CSR. Such awareness was primarily attributed to the Muslim religious orientation of the interviewees in that (as one public relations manager put it): "The teachings of Islam prescribe a clear guideline and thorough code of practice for any aspect of personal and organizational life. I believe that as long as we conform to these teaching instructions or as we call it Shariah, we have fulfilled our responsibilities and commitment to the society as a whole and conformed to the Islamic way of life. For us (Muslims), Shariah serves to protect the interests of the whole society which means people, businesses, no matter they are directly engaged with each other or indirectly affected by each other. So this is exactly what we mean by CSR".

Despite the importance attached to the Islamic teachings on promoting the socio-economic welfare, fulfilling the needs of the society as a whole and preserving the environment, the actual practice of these guidelines fell far short of its ideal. In the words of one HR manager: "While we are all aware of the fact that our religion, i.e., Islam, offer guidelines for all aspects of life, whether at home or at work or in society, I should say that we act differently in practice. As long as we can and as long as there is no legal pressure, we simply ignore it in practice for the sake of our own self-interest."

The Driving Force Behind CSR At the organizational level, the primary source of the management's awareness of CSR was due to their joint venture partnership with foreign automakers. However, our analysis of the interviews suggests the trivial impact of foreign partnership on the promotion of CSR. This is in spite of the fact that foreign auto makers in Iran's auto industry have worldwide reputation for promoting a multi-stakeholder approach toward embedding societal, economic, and environmental challenges into their corporate strategy, product/service offerings, and more importantly their interim and annual performance review.

Despite the foreign automakers' proactive approach to CSR in other developing countries, they tended to be rather passive toward the adoption and the diffusion of CSR practices in Iran's auto industry. As our interviews indicated, such lack of enthusiasm and active engagement in CSR activities could be attributed to several inhibitors. At the individual level, the antithetical and ambiguous nature of Iranian managers' mindsets seemed to pave the way for poor institutional governance mechanisms. In fact, the nature of managerial mindsets encouraged the foreign partners to do no more than pay lip service to the design 
and execution of CSR interventions. One explanation was that CSR was perceived by the senior management to be a synonym of (end) customer care and customer relations. Such loose usage of CSR was attributed to the dominant business-oriented mentality that guided the management of the three cases.

The Primary Focus of CSR For the majority of the interviewees, the adopted version of CSR by the foreign auto makers put the stress on operational and tactical improvement, thus conjuring up echoes of economic efficiency and labor productivity - at the price of - to quote an operations manager: "poor service and product quality, poor quality of life for the workers, and high rate of road traffic accident." Another explanation for the use of operational excellence as a guileless substitution for CSR was the view that the government was inclined to support the multinational car manufacturers for a very different reason, i.e., to counteract the country's industrial shortcomings and more importantly to deflect the US-led economic sanctions against the country (see Peimani 2003).

In pursuit of the operational benefits of the joint venture by the auto industry managers (i.e., fulfilling the minimum level of safety standards), our data indicates much less emphasis on the societal and environmental elements of CSR by the foreign automakers. The foreign partners were not keen to follow their global or MNC directives to sincerely engage in implicit and explicit CSR activities (see Jamali and Neville 2011, p. 610).

In the light of the preceding discussion, we suggest the following propositions:

Proposition 1 The diffusion of CSR practices is a direct function of the managerial mindset toward CSR.

Proposition 2 A managerial commitment to CSR that follows from partnership with foreign companies will result in an organization-wide lip service to CSR.

Proposition 3 The CSR approach of the foreign affiliate will vary according to the local managerial mindsets toward CSR.

\section{Divergence and Discrepancies}

In addition to the points of commonality observed across the three cases, the managerial mindsets toward CSR also differed markedly. Our interview data elucidated three types of managerial mindsets toward CSR. A brief account of these mindsets is given below.

Conformist Mindset In Automotive1, the dominant managerial mindset toward CSR was to pursue a compliance culture. This type of managerial mindset focuses on utilizing CSR interventions as "add-ons" for maintaining the current market share and retaining the repeat customers. As one HR manager put it, "It is always better to follow the norms and do not deviate from generally accepted norms of behavior... It is often the case that if we have new ideas it could have very negative connotations and consequently jeopardize our managerial position."

The observation by the HR manager highlights the rather static nature of CSR and the absence of a genuine quest for adopting CSR intervention as a stand-alone management strategy. A production manager's reflection on the overall managerial mindset toward CSR is illuminating: "We rarely reflect on the environmental impact of our operations and production methods based on the acceptable environmental performance metrics. This is because we perform far below the industry standards of our foreign partners. But the production never stops because we still can fulfill the minimum industry requirements."

Going beyond the compliance nature of the firm's CSR, there was no convincing evidence to suggest that the managerial approach toward CSR involved a distinctive departure from the prescribed, mandatory governmental regulations. For example, a senior HR consultant remarked that "Our commitment to the workforce and quality of their life is primarily limited to compliance with the labor law. We really do not pay attention to their participation in any voluntary social activity in a planned and rewarding manner." According to an environment, safety and health manager, "While road fatalities can be attributed to many factors including poor state of the roads and lack of a proper driving culture in the country, the priority area of focus from the top is to comply with the safety standards of our products."

During the focus group, some employees talked about the need for tackling the root causes of fatal casualties in road accidents in terms of being more socially responsible car manufacturer with regard to prompting a culture of traffic safety, initiating training and education programmes for young drivers, and sponsoring road safety education plan for the public. However, as the majority of interviewees remarked, such programmes were not expected to play a part in the management-led compliance plan and firm's approach to CSR. The lack of organizational focus on initiating these socially driven interventions for the interviewees was that (to quote one operations manager), "taking such initiatives on board would not necessarily protect the firm from non-compliance penalties and fines imposed by the government." In consequence, the actual practice of CSR in Automotive1 was found to be largely confined to the management-led compliance with multiple, often overlapping, auto industry regulations, and standards.

The conformist nature of the managerial mindset allowed the foreign partners some scope for variation 
from their global CSR interventions. Indeed it encouraged them to envisage a new version of CSR in that "compliance to the local management-defined working values and established standards of the industry" was perceived to enhance their legitimacy in the eyes of the management, the end customers and the government. As a result, we propose the following proposition:

Proposition 4 The type of managerial mindset that advocates CSR interventions as "add-ons" (rather than built-in) activity will promote a culture of compliance with minimum legal requirements.

Self-seeker In contrast to the compliance-oriented managerial mindset of Automotive1, the dominant managerial orientation of Automotive 2 mirrored an "inward-looking" mindset. As our interviews indicated, managers' quest for CSR was motivated purely by their self-centered and selfinterest tendency. Instead of adopting the CSR related best practices of its foreign partners, the management of Automotive2 appeared to pressurize the foreign partners to fulfill their self-centered priorities to the exclusion of those they serve-i.e., the stakeholders.

The observation by a senior HR advisor highlighted a different explanation for the dominant managerial mindset to CSR in the sense that he attributed the managerial mindset to the "ineffective system of executive-level appointments, the lack of managerial competence at the top level, and the importance of possessing experience in religious activities as a critical selection criterion for the appointment of top management team." Despite the continued appearance of the fundamental role of morality and ethics in Islamic teachings, the actual practice of CSR was rarely given much weight by the practicing managers. Instead, the enduring impression of the managerial appointment system was that it provided the senior management a one-dimensional approach to manage organizational practices. In the light of this discretion, as our evidence indicates, CSR activities were limited to a few community services which were primarily pursued through supporting healthcare, welfare, educational, and charitable institutions on an infrequent and ad hoc basis. Interestingly, such community supports were found to be granted without adequate diagnosis of the real problems facing the community. The key priority that drove allocation of budget for community services was the management's selfinterest and a token expression of their loyalty to Islam. This also served as a crucial mechanism to keep them in power. As our evidence indicates, apart from temporary philanthropic and charitable activities, other aspects of CSR-related issues such as a focus on supplier, employee, and environment were considered marginal activities rather than core values of the firm's CSR agenda.
Surprisingly, the foreign partners did not seem to make any attempt to go beyond the minimum operational necessities for car and auto parts production. As a senior sales executive remarked, "I do not think our foreignaffiliated automakers can find a more profitable and less challenging business environment than Iran. All they need to do is make cars in high volume which are of course of low quality to serve the price-conscious consumers. There is no local or external pressure or mechanism to force these companies to become socially responsible."

Given this research evidence, we can propose that:

Proposition 5 In the presence a self-centered managerial mindset toward CSR, there is a tendency on the part of foreign partners to only fulfill the immediate interest of the management and the shareholders.

Proposition 6 The CSR approach adopted by foreign partners is moderated by the managerial, organizational and governmental mandates that regulate the industry.

Satisfier A final dominant type of managerial mindset which was evident in Automotive3 focused on profit maximization and, to a lesser extent, it was a surrogate for improving product and service quality. In doing so, the management of Automotive3 placed a heavy focus on any functional area which had potential for increasing efficiency and opportunities for generating large cost savings. Several interviewees labeled this managerial mindset "a conventional accounting approach."

Such predominant desire to pursue the business fulfillment of core profit-making responsibility was, however, reflective of a much wider set of the organization's managerial behavior and auto industry dynamics which in turn impeded the organization to make concerted efforts to become more socially responsible. For the senior management team, the idea of profit maximization and pursuing a cost reduction strategy were seen as the chief priority to showcase their managerial competencies. The desire to maximize profit was widely viewed as a vital tool of maintaining job security at top managerial levels. One senior manager expressed the degree of relationship between his profit-seeking behavior and an elevated form of job security in the following remarks: "The current appointment and promotion system does not allow any room for specific circumstances... So it is not unusual for us to follow and achieve what they want; I mean selling more cars, making more profit, and contribute more to the government expenditures."

The dynamics of the auto industry also seemed to play a far more influential role in promoting managerial profitseeking behaviors. This was partially due to the highly state-centric nature of the industry which started with the implementation of an import substitution policy in the early 
1960s (see Alizadeh 1985; Abedini and Péridy 2009; Bahar 2005). Moreover, the stringent US-led international sanctions on Iran's energy sector and ongoing sharp drop in Iran's expected revenues from oil have forced the government to switch their attention to the flagship automotive industry as a means of compensating for the ongoing decrease in oil revenues.

The crucial implication of such dominant managerial approach for the firm's foreign-affiliated automakers was that it signaled an implicit rejection of CSR. The following example makes the nature and impact of the dominant profit-seeking managerial approach sufficiently clear: "It re-shifts the focus of our foreign partners from supporting a genuine CSR agenda to the one that only secures higher efficiency and improves the bottom-line. It also promotes an organization-wide culture of prioritizing cost over customer" (Senior Manager for International Operations). The practical outcomes of the managerial profit-centric or selfseeker mindset were open to doubts, and rarely recognized as CSR-related activities by the interviewees.

Given the above evidence, it can be proposed that:

Proposition 7 A profit-oriented managerial approach toward CSR will only result in a partial acceptance of CSR by both organizational members and foreign partners, in that they only promote CSR to fulfill their own personal interests.

Proposition 8 In the presence of a profit-oriented managerial approach toward CSR, as well as economic instability, the foreign partners will pay lip service to CSR practice.

Proposition 9 The managerial approach of the foreign affiliates toward CSR will vary across different countries with different degrees of economic development and stability.

\section{Discussion and Conclusions}

In view of the intense pace of globalization and emergingmarket expansion, recent CSR research has moved away from a focus on the societal, environmental, and economic impact of the Western-dominated business operations to the examination of CSR in the non-Western regions, such as the Middle East (see Ahmed and Donnan 1994; Beekun and Badawi 2005; Maak and Pless 2009; Ramadan 2009). Given the limited scholarship on Islamic CSR and business ethics in the global economy (see Metcalfe 2008; Metcalfe and Rees 2010), coupled with Islamic resurgence and the dearth of research on "managerial attitudes toward CSR" (see Waldman et al. 2004), this study provides empirical insights into the managerial mindset toward CSR in the
Muslim-dominated region of the Middle East (Metcalfe and Syed 2012).

Using three cases from one of the fastest growing industries in Iran-i.e., auto industry-we elucidated three types of managerial mindset toward CSR, i.e., conformist, self-seeker, and satisfier. In the light of the identified managerial mindsets, we also suggested several working propositions for future empirical scrutiny and testing. A discussion of the implications of the findings is given below.

The first implication of the study arises from the finding that the identified managerial mindsets toward CSR do not bring corporate behavior up to a level where it is congruent with prevailing Islamic cultural and societal norms, values, and expectations of performance (Sethi 1975, p. 62; Carroll 1999, p. 279). Owing to its Islamic identity, one might expect the CSR managerial mindsets in Iran to be influenced by the holistic spiritual view based on the teachings of the Qur'an and the Sunnah (Ahmad 2002; Wilson 2001; Dusuki 2008; Ahmad and Sadeq 2001. However, the peculiarities of the managerial mindsets coupled with the politicized nature of the Islamisation by the Iranian government seemed to have little interest in adopting CSR as a business practice (see Ahmed and Donnan 1994; Platteau 2010; Metcalfe and Syed 2012). Rather, the identified managerial mindsets appeared to be pivoted on the "unenlightened self-interest" and a desire to act in accordance with their own myopic selfishness (de Tocqueville 2000; Steenbergen 1935; Griffiths and Lucas 1995). In this sense, the dominant managerial mindsets of top managers as having little or no interest in CSR fostered a culture of compliance with "the (minimum) regulatory safety standards of auto industry" at lower hierarchical levels. Owing to its multidisciplinary nature, the study contributes to theory development in the broad area of managerial leadership of CSR interventions (see Waldman et al. 2004; Mendonca 2001; Kanungo 2001; Hillman and Keim 2001; Bass and Steidlmeier 1999) and highlights the need for further empirical scrutiny of the managerial leadership of CSR as a "context-dependent" — as opposed to a "universal" — phenomenon (see Waldman et al. 2004).

Second contribution of the study centers on the potential role of foreign affiliates in determining the propensity of local firms to engage in CSR activities. While anecdotal evidence on the application and positive ramifications of CSR interventions of multinational firms in less developed and developing countries is well documented (Matten and Moon 2008; Fukukawa and Teramoto 2009; Jamali 2007; Cheung et al. 2010; Yin 2012; Khan et al. 2013), the foreign car makers operating in Iran's auto industry were keen to take advantage of the Iranian managers' passive approach toward CSR. Such passive and partial approach of foreign partners toward the fulfillment of the local 
management self-interests was partially attributed to the fact that the car industry constituted one of the country's most profitable industry and that most of the foreignaffiliated automakers operating suffered large operating losses in the light of the recent credit crunch which seriously dampened consumers' demand for new vehicles across the global market. Our findings warn of the false seduction of the developmental promise of foreign firms' adoption and implementation of CSR in developing countries. While the foreign firms operating in Iran's auto industry could have done more to go beyond profit making and impose mandatory safety standards, they seemed to benefit commercially from the governance failure by negotiating more profitable business agreements with the government (see Jedrzej 1998). This was partially due to the ongoing US-led economic sanctions on Iran which primarily targeted the country's energy sector. The farreaching implications of the most recent US-led sanctions on the country's currency and auto industry (Felsenthal et al. 2013) are twofold: a pressing need for the government to seek new sources of revenue for the government expenditure, and limits to the extent to which managerial actions of foreign affiliates in Iran's auto industry bring about a marked transformation of business-governmentsociety relations (see Chapardar and Khanlari 2011).

Third contribution of the study relates to a need to reassess conceptualizations of CSR and business ethics from an Islamic perspective. While a plethora of past research has tended to conceptualize CSR as a mechanism to take the lead in the sustainable development of the society as a whole in Western-dominated organizational contexts (Wood 1991; Matten and Moon 2008; Visser et al. 2007; Carroll and Shabana 2010), our study has made an attempt to examine the CSR management in one of the largest Muslim-majority countries in the Middle East region i.e., Iran. Given the current Islamic resurgence in an era of economic globalization which may reinforce Samuel Huntington's (1996) influential "clash of civilizations" hypothesis, and the rise of political Islam in the Middle East region which could hinder businesses to deliver societal, economical, and environmental developments (see Ahmed and Donnan 1994; Platteau 2010; Metcalfe and Syed 2012), our findings (consistent with those of Crane and Matten's study of comparative CSR-2004, Habisch et al.'s emphasis on the contingency nature of CSR practices-2005, Gjolberg's study of national CSR practices2009, and McKinsey and Company's report on differences in adopted CSR strategies across the world-2007) suggest to revisit conceptualizations of CSR as a context-dependent phenomenon.

In the light of these findings, it is imperative for practicing managers to be mindful of the following two concerns. First, managerial leadership of CSR has to go beyond the tactical, operational, and instrumental use of CSR to encompass other strategic rationale, such as adopting CSR for moral or ethical reasons. It is argued that such strategic approach toward CSR is a surrogate for and indeed key to effective leadership (Daft 2002). Second, the dual fulfillment of core profit-making responsibility and business responsibility for some of the wider societal good (McWilliams and Siegel 2001) necessitates a transformational leadership which has the capacity to maintain an optimal level of CSR-i.e., simultaneous use of CSR to maximize profit and satisfy demand for CSR emanating from various stakeholder groups (see McWilliams and Siegel 2001; Waldman et al. 1998, 2004, p. 3).

Building on these findings, the onus is on the policy makers to be more active in creating a business environment which lives up to the contextual and global CSR and ethical standards. Given the current policy of the Iranian government to support its auto industry in the face of the fast-growing domestic demand, and the ongoing U.S. led sanctions (see Peimani 2003; Felsenthal et al. 2013), it is of paramount importance for the Iranian government to revisit its societal governance and act as a primary driver and enabler of CSR.

Acknowledgments This work was supported by the Economic and Social Research Council (ESRC) grant to the lead author [grant number RES-000-22-4227].

\section{References}

Ackerman, R. W. (1975). The social challenge to Business. Cambridge: Harvard University Press.

Abedini, J., \& Péridy, N. (2009). The emergence of Iran in the world car industry: An estimation of its export potential. Journal compilation, Blackwell Publishing Ltd.

Ahmad, K. (2002). Islamic ethics in a changing environment for managers. In A. H. M. Sadeq (Ed.), Ethics in business and management: Islamic and mainstream approaches. London: Asean Academic Press.

Ahmed, A. S., \& Donnan, H. (Eds.). (1994). Islam, globalization and postmodernity. London, UK: Routledge.

Ahmad, K., \& Sadeq, A. H. M. (2001). Islamic ethics in a changing environment for managers. In K. Ahmad \& A. H. M. Sadeq (Eds.), Ethics in business and management Islamic and mainstream approaches. London: Asean Academic Press.

Al-Attas, S. M. N. (1996). The world view of Islam: An outline. In S. S. Al-Attas (Ed.), Islam and the challenge of modernity. Kuala Lumpur: International Institute of Islamic Thought and Civilization (ISTAC).

Alizadeh, P. (1985). The process of import-substitution industrialization in Iran (1960-1978): With particular reference to the case of motor vehicle industry. University of Sussex: Unpublished D.Phil. 1985.

Amuzegar, J. (1991). The dynamics of the Iranian revolution. New York: The State University of New York Press.

Amuzegar, J. (1997). Iran's economy and the US sanctions. Middle East Journal, 51(2), 185-199.

Bahar, A., (2005). 'Reports on Iran's automotive sector,' Atieh Bahar Consulting Firm, Tehran, Iran. www.atiehbahar.com. 
Bansal, P., \& Roth, K. (2000). Why companies go green: A model of ecological responsiveness. Academy of Management Journal, 43(4), 717-736.

Barker, C., Pistrang, N., \& Elliot, R. (2002). Research method in clinical psychology. Chichester: Wiley.

Bass, B. M., \& Steidlmeier, P. (1999). Ethics, character, and authentic transformational leadership behavior. Leadership Quarterly, 10, $181-217$

Beekun, R., \& Badawi, J. (2005). Balancing ethical responsibility among multiple organisational stakeholders: The Islamic perspective. Journal of Business Ethics, 60(2), 131-145.

Bhattacharya, C. B., Sankar, S., \& Korschun, D. (2008). Using corporate social responsibility to win the war for talent. MIT Sloan Management Review, 49(2), 37-44.

Bowen, H. R. (1953). Social responsibility of businessman. New York: Harper-Row.

Carroll, A. (1999). Corporate social responsibility: Evolution of a definitional construct. Business Society, 38(3), 268-295.

Carroll, A. B., \& Shabana, K. M. (2010). The business case for corporate social responsibility: A review of concepts, research and practice. International Journal of Management Review, 12(1), 85-105.

Chambers, E., Chapple, W., Moon, J., \& Sullivan, M. (2003). CSR in Asia: A seven country study of CSR website reporting, ICCSR Research Papers No. 10.

Chapardar, H., \& Khanlari, R. (2011). Iranian corporations and corporate social responsibility: An overview to adoption of CSR themes. Sage Open. doi:10.1177/2158244011430988.

Chase, S., Ruttenberg, S. H., Nourse, E. G., \& Given, W. B, Jr. (1950). The social responsibility of management. New York: New York University.

Cheung, Y. L., Tan, W. Q., Ahn, H. J., \& Zhang, Z. (2010). Does corporate social responsibility matter in Asian emerging markets? Journal of Business Ethics, 92, 401-413.

CIA - the world Factbook. (2013). International Organizations and Groups. Accessed 6 June, 2013, from http://www.cia.gov/library/ publications/the-world-factbook/appendix/appendix-b.html.

Cohen, J. (1960). A coefficient of agreement for nominal scales. Educational and Psychological Measurement, 20, 37-46.

Crane, A., Matten, D., \& Moon, J. (2008). Corporations and citizenship. Cambridge: Cambridge University Press.

Creswell, J. W. (2005). Educational research: Planning, conducting, and evaluating quantitative and qualitative research (2nd ed.). Upper saddle river, NJ: Pearson Education.

Cullen, J. B., Parboteeah, K. P., \& Hoegl, M. (2004). Cross-national differences in managers' willingness to justify ethically suspect behaviors: A test of institutional anomie theory. Academy of Management Journal, 47, 411-421.

Daft, R. L. (2002). The leadership experience (2nd ed.). Cincinnati, $\mathrm{OH}$ : South-Western.

de Tocqueville, A. (2000). Democracy in America. (Originally published 1835). Chicago: University of Chicago Press.

Denzin, N. K., \& Lincoln, Y. S. (Eds.). (1994). Handbook of qualitative research. Thousand Oaks: Sage.

Donaldson, T., \& Dunfee, T. W. (1999). Ties that bind: A social contract approach to business ethics. Boston: Harvard Business School.

Dubowitz, M. (2013). Iran's car industry-A big sanctions buster. Available http://www.forbes.com/sites/energysource/2013/05/ 13/irans-car-industry-a-big-sanctions-buster/.

Dusuki, A. W. (2008). What does Islam say about Corporate Social Responsibility (CSR)? Review of Islamic Economics, 12(1), 2-28.

Dusuki, A. W., \& Bouheraoua, S. (2011). The framework of Maqasid al-Shariah (objectives of the Shari'ah) and its implications for islamic finance. ISRA Research Paper (No: 22/2011). Kuala Lumpur: International Institute of Advanced Islamic Studies.
Egri, C. P., Ralston, D. A., Milton, L., Casado, T., Palmer, I., Ramburuth, P., et al. (2006). The influence of personal values and national contexts on attitudes towards corporate responsibilities. Presented at the third $\mathrm{BC}$ organizational behaviour conference, Vancouver, Canada.

Eisenhardt, K. (1989). Building theory from case study research. Academy of Management Review, 14, 532-550.

Eisenhardt, K. M., \& Graebner, M. E. (2007). Theory building from cases: Opportunities and challenges. Academy of Management Journal, 50(1), 25-32.

Encyclopedia Britannica. (2013). Middle East. Accessed 12 May, 2013, from http://global.britannica.com/EBchecked/topic/381192/ Middle-East.

Eshghipour, K. (2013). The Islamic Revolution's impact on the legal and social status of Iranian women. Iranian chamber society. Available http://www.iranchamber.com/society/articles/islamic_ revolution_status_women.php.

Farah, C. (1994). Islam: Beliefs and observances (5th ed.). New York: Barron's Educational Series.

Felsenthal, M., Yukhananov, A. \& Gardner, T. (2013). U.S. targets Iran with currency, auto-sector sanctions. Reuters. Available http:// in.reuters.com/article/2013/06/03/usa-iran-sanctions-idINDEE 9520H620130603.

Freeman, E. (1984). Strategic management: A stakeholder approach. New York: Basic Books.

Friedman, M. (1970, September 13). The social responsibility of business is to increase its profits. The New York Times Magazine.

Fukukawa, K., \& Teramoto, Y. (2009). Understanding Japanese CSR: The reflection of managers in the field of global operations. Journal of Business Ethics, 85, 133-146.

Glaser, B. G., \& Strauss, A. L. (1967). The discovery of grounded theory. Chicago: Aldine.

Griffiths, M. R., \& Lucas, J. R. (1995). Ethical economics. Tuscany: Oxford and Somerset.

Griffiths, M. R., \& Lucas, J. R. (1996). Ethical economics. Palgrave MacMillan.

Guba, E. (1978). Toward a methodology of naturalistic inquiry in educational evaluation (Monograph No. 8). Los Angeles: UCLA Center for the Study of Evaluation.

Guba, E. G., \& Lincoln, Y. S. (1994). Competing paradigms in qualitative research. In N. K. Denzin \& Y. S. Lincoln (Eds.), Handbook of qualitative research (pp. 105-117). Thousand Oaks, CA: Sage.

Harris, L. C., \& Ogbonna, E. (2002). The unintended consequences of culture interventions: A study of unexpected outcomes. British Journal of Management, 13(1), 31-49.

Hay, R., \& Gray, E. (1974). Social responsibilities of business managers. Academy of Management Journal, 17, 135-143.

Hemingway, C. A. (2005). Personal values as a catalyst for corporate social entrepreneurship. Journal of Business Ethics, 60(3), 233-249.

Hillman, A., \& Keim, G. (2001). Shareholder value, stakeholder management and social issues: What's the bottom line? Strategic Management Journal, 22(2), 125-139.

Hofstede, G. (2001). Culture's consequences: Comparing values, behaviors, institutions, and organizations across nations. Thousand Oaks, CA: Sage.

House, R. J., Hanges, P. M., Javidan, M., Dorfman, P., \& Gupta, V. (2004). Culture, leadership and organizations: The GLOBE study of 62 societies. Thousand Oaks, CA: Sage.

Huntington, S. P. (1996). The clash of civilizations and the remaking of world order. New York: Simon \& Schuster.

Ilias, S. (2009). Iran's economic conditions: U.S. policy issues. Congressional Research Service, no. 7-5700. Accessed 5 June, 2013, from http://www.crs.gov.

Jamali, D. (2007). The case for strategic corporate social responsibility in developing countries. Business and Society Review, 112, 1-27. 
Jamali, D., \& Mirshak, R. (2007). Corporate social responsibility (CSR): Theory and practice in a developing country context. Journal of Business Ethics, 72(3), 243-262.

Jamali, D., \& Neville, B. (2011). Convergence versus divergence of CSR in developing countries: An embedded multi-layered institutional lens. Journal of Business Ethics, 102, 599-621.

Jamali, D., \& Sidani, Y. (2012). CSR in the middle east: Fresh perspectives. In D. Jamali \& Y. Sidani (Eds.), Introduction: CSR in the middle east: Fresh perspectives (pp. 1-11). UK: Palgrave Publishers.

Javidan, M., \& Carl, D. E. (2004). East meets West: A cross-cultural comparison of charismatic leadership among Canadian and Iranian executives. Journal of Management Studies, 41(4), 665-691.

Javidan, M., \& Dastmalchian, A. (1998). High-commitment leadership: A study of Iranian executives. Journal of Comparative International Management, 1(1), 23-32.

Javidan, M., \& Dastmalchian, A. (2003). Culture and leadership in Iran: The land of individual achievers, strong family ties, and powerful elite. Academy of Management Executive, 17(4), 127-142.

Jedrzej, G. F. (1998). The false developmental promise of corporate social responsibility: Evidence from multinational oil companies. International affairs, 81(3), 581-598.

Kantarelis, D. (2007). Theories of the firm (2nd ed.). Switzerland: Inderscience Enterprise Ltd.

Kanungo, R. N. (2001). Ethical values of transactional and transformational leaders. Canadian Journal of Administrative Sciences, $18,257-265$

Katzman, K. (2013). Iran sanctions. Congressional Research Service, no. 7-5700. Accessed 6 June, 2013, from http://www.crs.gov.

Khan, A., Muttakin, M. B., \& Siddiqui, J. (2013). Corporate governance and corporate social responsibility disclosures: Evidence from an emerging economy. Journal of Business Ethics, 114(2), 207-223.

Kytle, B., \& Singh, P. (2005). Corporate social responsibility as risk management: A model for multinationals, social responsibility initiative (Working Paper No. 10), John F. Kennedy School of Government, Harvard University, Cambridge, MA.

Landis, J. R., \& Koch, G. G. (1977). The measurement of observer agreement for categorical data. Biometrics, 33, 159-174.

Lincoln, Y. S., \& Guba, E. (1985). Naturalistic enquiry. Beverly Hills, CA: Sage.

Maak, T., \& Pless, N. M. (2009). Business leaders as citizens of the world. Advancing Humanism on a global scale. Journal of Business Ethics, 88(3), 537-550.

Makhija, M. V., Kim, K., \& Williamson, S. D. (1997). Measuring globalization of industries using a national industry approach: Empirical evidence across five countries and over time. Journal of International Business Studies, 28(4), 679-710.

Mather, D., Mather, Y. \& Tamjidi, M. (2007). Making cars in Iran: Working for Iran Khodro. Critique, 35(1), 9-21.

Matten, D., \& Moon, J. (2008). 'Implicit' and 'explicit' CSR: A conceptual framework for a comparative understanding of Corporate Social Responsibility. Academy of Management Review, 33(2), 404-424.

Maykut, P., \& Morehouse, R. (1994). Beginning qualitative research: A philosophic and practical guide. London: Falmer Press.

McWilliams, A., \& Siegel, D. (2001). Corporate social responsibility: A theory of the firm perspective. Academy of Management Review, 26, 117-127.

Mehler, C. (2008). National Geographic atlas of the Middle East. Washington, DC: National Geographic.

Mendonca, M. (2001). Preparing for ethical leadership in organizations. Canadian Journal of Administrative Sciences, 18, 266-276
Metcalfe, B. D. (2008). Women, management and globalization in the Middle East. Journal of Business Ethics, 83(1), 85-100.

Metcalfe, B. D., \& Rees, C. R. (2010). Gender, globalization and organization: Exploring power, relations and intersections. Equality, Diversity and Inclusion: An International Journal, 29(1), 5-22.

Metcalfe, B. D. \& Syed, J. (2012). Globalization, development and Islamic business Ethics. Call for papers for the Special Issue of Journal of Business Ethics.

Miles, M. B., \& Huberman, A. M. (1994). Qualitative data analysis. Beverly Hills, CA: Sage.

Momen, M. (1985). An Introduction to Shi' 'i Islam: The History and Doctrines of Twelver Shi 'ism. Oxford: George Ronald.

Moon, J., Crane, A., \& Matten, D. (2005). Can corporations be citizens? Corporate citizenship as a metaphor for business participation in society. Business Ethics Quarterly, 15(3), 427-451.

O'Reilly, C., \& Chatman, J. (1996). Culture as social control: Corporations, cults, and commitment. Research in organizational behavior, 18, 157-200.

O'Donoghue, T., \& Punch, K. (2003). Qualitative educational research in action: Doing and reflecting (p. 78). New York: Routledge.

Ogbonna, E., \& Wilkinson, B. (2003). The false promise of organizational culture change: A case study of middle managers in grocery retailing. Journal of Management Studies, 40(5), 1151-1178.

Paluszek, J. (2005). Ethics and brand value: Strategic differentiation. Powerpoint presentation at the business and organizational ethics partnership meeting at the markkula center for applied ethics, Santa Clara University, April 6-7.

Peimani, H. (2003). Russia Turns to Iran for Oil Exports. Asia Times, February 11. Accessed 25 May, 2012, from http://www.atimes. com/atimes/Central_Asia/EB11Ag03.html.

Penrose, E. T. (1959). The theory of the growth of the firm. New York: John Wiley.

Platteau, J.-P. (2010). Political instrumentalization of Islam and the risk of obscurantist deadlock. World Development, 39(2), 243-260.

Porter, M. E. (1986). Competition in global industries: A conceptual framework. In M. E. Porter (Ed.), Competition in global industries (pp. 15-60). Boston, MA: Harvard Business School Press.

Quazi, A. M. (1997). Corporate social responsibility in diverse environments: A comparative study of managerial attitudes in Australia and Bangladesh. Business and Professional Ethics Journal, 16, 67-84.

Quazi, A. M., \& O’Brien, D. (2000). An empirical test of a crossnational model of corporate social responsibility. Journal of Business Ethics, 25, 33-51.

Ramadan, T. (2009). Radical reform: Islamic ethics and liberation. Oxford: Oxford University Press.

Recknagel, C. (2013). As sanctions are relaxed, western businesses look to Iran. Available http://www.rferl.org/content/iran-tradebusiness-reaction-sanctions-lifted-nuclear/25236337.html.

Rees, R. (1985). The theory of principal and agent-Part I. Bulletin of Economic Research, 37(1), 3-26.

Russo, M., \& Fouts, P. (1997). A resource-based perspective on corporate environmental performance and profitability. Academy of Management Journal, 40(3), 534-559.

Samani, M. B., Attafar, A., \& Khouzani, N. K. (2011). A conceptual model for Iran's car industry customers' loyalty. Proceedings of the 2nd International Conference on Business and Economic Research (2nd ICBER 2011).

Schein, E. H. (1992). Organizational culture and leadership. San Tranciso: Jossey-Bass. 
Schwartz, S. H. (1994). Cultural dimensions of values: Towards an understanding of national differences. In H. C. Kim, C. Triandis, C. Kagitcibasi, S. C. Choi, \& G. Yoon (Eds.), Individualism and collectivism: Theoretical and Methodological Issues (pp. 85-119). Thousand Oaks, Calif: Sage.

Sethi, S. P. (1975). Dimensions of corporate social performance: An analytical framework. California Management Review, 17(3), $58-64$.

Sheth, H., \& Babiak, K. M. (2010). Beyond the game: Perceptions and practices of corporate social responsibility in the professional sport industry. Journal of Business Ethics, 91(3), 433-446.

Sirmon, D. G., \& Lane, P. J. (2004). A model of cultural differences and international alliance performance. Journal of International Business Studies, 35, 306-319.

Spicer, A., Dunfee, T. W., \& Bailey, W. J. (2004). Does national context matter in ethical decision making? An empirical test of integrative social contracts theory. Academy of Management Journal, 47, 610-620.

Steenbergen, J. B. (1935). Enlightened self-interest. Learning to give. Available http://www.learningtogive.org/papers/paper23.html.

Storey, J. (1992). Developments in the management of human resources. Oxford: Blackwell.

Swanson, D. L. (2008). Top managers as drivers for corporate social responsibility. In A. Crane, D. Matten, A. McWilliams, J. Moon, \& D. Siegel (Eds.), The Oxford Handbook of Corporate Social Responsibility (pp. 227-248). Oxford, UK: Oxford University Press.

Syed, J. (2009). Reconstruction of gender in Islamic thought: Iqbal's vision of equal opportunity. Women's Studies International Forum, 32(6), 435-444.

The Free Dictionary. (2013). Mindset. Accessed 21 April, 2013, from http://www.thefreedictionary.com/mindset.

The Free Dictionary.com. (2013). Accessed 10 May, 2013, from http://www.thefreedictionary.com.

Triandis, H. C. (1995). Individualism and collectivism. Boulder, Colo: Westview Press.

Visser, W. (2011). The age of responsibility: CSR 2.00 and the new DNA of business (2nd ed.). London: Wiley.

Visser, W., Matten, D., Pohl, M., \& Tolhurst, Nick (Eds.). (2007). The A to $Z$ of corporate social responsibility. London: Wiley.

Vitell, S. J., \& Paolillo, J. G. (2004). A cross-cultural study of the antecedents of the perceived role of ethics and social responsibility. Business Ethics, 13(2-3), 185-199.

Waldman, D. A., Lituchy, T., Gopalakrishnan, M., Laframboise, Galperin, B., \& Kaltsounakis, Z. (1998). A qualitative analysis of leadership and quality improvement. Leadership Quarterly, 9(2), 177-201.

Waldman, D., Siegel, D., \& Javidan, M. (2004). CEO transformational leadership and corporate social responsibility (working paper number 0415). NY, USA: Rensselaer Working Papers in Economics, Department of Economics, Rensselaer Polytechnic Institute.

Waldman, D. A., Sully de Luque, M., Washburn, N., \& House, R. J. (2006). Cultural and leadership predictors of corporate social responsibility values of top management: A GLOBE study of 15 countries. Journal of International Business Studies, 37, $823-837$.

Williams, C. A. \& Aguilera, R. V. (2007). Corporate social responsibility in a comparative perspective. In A. Crane, D. Matten, \& L. Spence (Eds.), Corporate social responsibility: readings and cases in global context (pp. 452-472). London: Routledge.

Williams, G., \& Zinkin, J. (2010). Islam and CSR: A study of the compatibility between the tenets of Islam and the UN global compact. Journal of Business Ethics, 91, 519-533.

Wilson, R. (2001). Business ethics: Western and Islamic perspectives. In K. Ahmad \& A. M. Sadeq (Eds.), Ethics in business and management. London: Asean Academic Press.

Wood, D. J. (1991). Corporate social performance revisited. Academy of Management Review, 16, 691-718.

Wright, R. (2010). The Iran Primer: Power, Politics and U.S. Policy. United States Institute of Peace (USIP) Press Books.

Wright, R. (2012). The Islamists are coming: Who they really are. The U.S. Institute of Peace (USIP) Press Books. http://www. robinwright.net. Accessed 1 June 2013.

Wright, P., \& Ferris, S. (1997). Agency conflict and corporate strategy: The effect of divestment on corporate value. Strategic Management Journal, 18, 77-83.

Wu, Z., \& Choi, T. Y. (2005). Supplier-supplier relationships in the buyer-supplier triad: Building theories from eight case studies. Journal of Operations management, 24(1), 27-52.

Yin, R. K. (2003). Case study research: Design and methods (3rd ed.). Thousand Oaks, CA: Sage.

Yin, R. K. (2009). Case study research: Design and methods (4th ed.). Thousand Oaks, CA: Sage.

Yin, J., \& Zhang, Y. (2012). Institutional dynamics and corporate social responsibility (CSR) in an emerging country context: Evidence from China. Journal of Business Ethics, 111(2), 301-316.

Yukl, G. A. (2012). Leadership in organizations (8th ed.). Upper Saddle River, NJ: Prentice Hall. 